International Research Journal of Management, IT \& Social Sciences
Available online at https://sloap.org/journals/index.php/irjmis/
Vol. 7 No. 1, January 2020, pages: 104-115
ISSN: 2395-7492
https://doi.org/10.21744/irjmis.v7n1.827

\title{
The Role of Profitability in Mediating Company Ownership Structure and Size of Firm Value in the Pharmaceutical Industry on the Indonesia Stock Exchange
}

Made Jelita Sugosha ${ }^{a}$ Luh Gede Sri Artini ${ }^{\text {b }}$

Article history:

Submitted: 09 November 2019

Revised: 18 December 2019

Accepted: 04 January 2020

\section{Keywords:}

firm size;

firm value;

Indonesia stock exchange;

ownership structure;

profitability;

\begin{abstract}
The purpose of this study was to examine the effect of ownership structure, firm size, and profitability on firm value. The research model was built by placing profitability measured by Return on Equity (ROE) as a mediating variable on the effect of ownership structure and firm size on the firm value measured by Price to Book Value (PBV). The study was conducted on the Pharmaceutical Industry in the Indonesia Stock Exchange for the period 20132018 , with a total sample of 42 obtained by purposive sampling technique and analyzed by path analysis method. The results showed that foreign ownership had a significant positive effect on profitability but did not have a significant positive effect on firm value. Managerial ownership has no significant positive effect on profitability and no significant negative effect on firm value. Institutional ownership does not have a significant positive effect on profitability and firm value. The firm size has a significant positive effect on profitability but does not have a significant positive effect on firm value. Profitability has a significant positive effect on firm value. The role of profitability as mediation in this study was tested by calculating the value of sobel. The results show that profitability is able to mediate foreign ownership of firm value with a sobel value of 2.181 and profitability is able to mediate the firm size against firm value with a sobel value of 2.159.
\end{abstract}

International research journal of management, IT and social sciences (C) 2020. This is an open access article under the CC BY-NC-ND license (https://creativecommons.org/licenses/by-nc-nd/4.0/).

\section{Corresponding author:}

Made Jelita Sugosha,

Faculty of Economics and Business, Udayana University, Denpasar, Indonesia

Email address: lita.sugosha@gmail.com

Udayana University, Denpasar, Indonesia

Udayana University, Denpasar, Indonesia 
1 Introduction

Investors in making investment decisions must analyze companies that have good company performance and value. Good firm value can be achieved if the manager performs good corporate governance. Good corporate governance or better known as Good Corporate Governance is a system or concept that is applied in managing a company with the main objective of increasing shareholder value in the long run while still taking into account the interests of stakeholders. The implementation of good governance will have a positive impact on the business environment and increase the confidence of stakeholders, especially investors, to the company.

Most of the pharmaceutical industry has realized the importance of Good Corporate Governance (GCG) practices within the company. Good GCG practices are the key to achieving sustainable growth. Managerial must ensure that all business activities are carried out ethically and responsibly, based on the applicable rules and regulations.

Firm value is the main goal for a company. For investors, firm size is an important concept because firm size is an indicator of how the market sees the company, where high firm values lead to good corporate performance (Rahman, 2014). According to Brigham \& Daves (2016), the ratio of stock market value and book value can be a measure for investors in looking at a company. Price to book value (PBV) is the ratio between the stock market value and the book value of a company (Brigham \& Houston, 2010). PBV is used to show the ability of a company to be able to create a firm size for the amount of capital invested. The higher the ratio means that the company is better at creating value for shareholders (Hirdinis, 2019).

The ownership structure is one of the important aspects that can be used to reduce agency conflicts within the company, especially in the distribution of dividends to shareholders. Agency problems arise as a result of the separation of duties between the company management and shareholders. Agency conflict or agency conflict usually occurs between shareholders and creditors, internal owners (managers) and external owners of the company, as well as between shareholders and company managers. These conflicts can lead to a reduction in firm value (Brigham \& Dave, 2016).

According to Ali \& Miftahurrohman (2014), ownership structure has a significant positive effect on dividend policy. This means that the higher the structure of corporate stock ownership either by insider ownership or institutional ownership affects the increase in dividend payouts (Herni, 2014). However, an increase in the structure of share ownership does not affect the firm value (Herni, 2014).

Research conducted by Zakaria et al. (2014), shows that foreign ownership has a positive effect on firm value. According to research conducted by Karima (2017), managerial ownership has a significant effect on firm value. A positive relationship was also shown between institutional ownership and firm value in research conducted by Faidah (2018). Other studies also show different results, where managerial ownership and institutional ownership do not have a positive and significant effect on firm value (Hasan, 2015).

The investment policies adopted in the pharmaceutical industry certainly also affect the firm size. The large firm size indicates that the company is experiencing growth, so investors will respond positively, and the firm value will increase. The greater the total assets and sales, the greater the firm size, thus the firm size reflects the size or number of assets owned by the company and has an influence on the firm value (Horne \& Wachowicz, 2009).

Several studies have shown that firm size has a significant positive effect on firm value (Khoiro et al., 2017; Tui et al., 2017). However, a negative relationship between firm size and firm value is also found in other studies where the greater the firm size turned out to show the firm value did not increase (Willim, 2015). can be overcome by using profitability as a mediating variable. Profitability certainly can also be a benchmark for investors to assess a company.

According to agency theory, high profitability means fulfilling the agent's responsibilities to the principal. Profitability in this case Return on equity (ROE) is a ratio that shows a company's ability to generate net income for a return on shareholders' equity. The greater the ROE results, the better the company's performance. The presence of ROE growth shows a better prospect for the company because it means the potential increase in profits earned by the company. Profitability growth is captured by investors as a positive signal from the company that will increase investor confidence and will facilitate company management to attract capital in the form of shares (Hirdinis, 2019). ROE is known to have an influence on firm value as measured by PBV (Majid \& Benazir, 2015; Rahma et al., 2017; Tui et al., 2017).

The concentration of ownership is also known to be a relevant positive predictor of profitability measured in terms of ROE (Mule et al., 2015). Research on foreign ownership shows a positive relationship with company performance as measured by company profitability (Zakaria et al., 2014; Lukas \& Basuki, 2015; Musallam, 2015; Herawanto et al., 2017; Zraiq \& Fadzil, 2018). Management ownership is also known to have a significant positive effect on ROE or the

Sugosha, M. J., \& Artini, L. G. S. (2020). The role of profitability in mediating company ownership structure and size of firm value in the pharmaceutical industry on the Indonesia stock exchange. International Research Journal of Management, IT and Social Sciences, 7(1), 104-115. https://doi.org/10.21744/irjmis.v7n1.827 
company's financial performance (Zakaria et al., 2014 and Lawal et al., 2018). Previous research also revealed that institutional ownership can encourage companies to increase ROE (Lawal et al., 2018).

Several studies have also been conducted to investigate the relationship between firm size and profitability, where the results of the study indicate that firm size has a positive influence on profitability (Khoiro et al., 2017; Tui et al., 2017). Research conducted by Mule et al., (2015), proves that firm size is an important positive predictor of profitability as measured by ROE.

Differences in research results related to profitability, ownership structure, firm size, and firm value are the basis for researchers to use profitability as a mediating variable. Research with profitability as a mediating variable, especially in the pharmaceutical industry, has also not been done much, so the role of profitability in mediating the ownership structure and firm size on firm value in the Pharmaceutical Industry on the Indonesia Stock Exchange is interesting to analyze. The results of this study are expected to be the basis for investors and companies to consider the best investment decisions, especially in the Indonesian pharmaceutical industry sector.

\section{Literature Review and Hypotheses Ownership Structure}

The ownership structure is the distribution of share ownership in a company. The structure of corporate ownership consists of foreign ownership, managerial ownership and institutional ownership. Foreign ownership can be one of the supporting mechanisms of corporate governance because companies with foreign ownership will increase corporate market competition. Foreign investors can usually help improve management systems and easier access to resources so that it will support companies to improve company performance and obtain greater profits. According to Shrivastav \& Kalsie (2017), the research shows that foreign ownership has a positive effect on company performance/profitability as measured by ROE. Other research also shows that foreign ownership has a positive effect on company profitability as measured through ROA and ROE (Zakaria et al., 2014; Lukas \& Basuki, 2015; Musallam, 2015; Herawanto et al., 2017; Zraiq \& Fadzil, 2018).

Managerial ownership (managerial ownership) is a proxy for share ownership by management in the company so that in addition to acting as a manager, management is also a shareholder of the company or insider ownership (Fahdiansyah et al., 2018). Managerial ownership is recognized as having an important mechanism that raises agency problems (Alabdullah, 2016). Increasing managerial ownership can reduce agency problems that occur in the company because managers tend to prioritize the interests of the company. According to previous studies, it was found that there was a significant relationship between managerial stock ownership and company performance/profitability as measured by ROE (Gugong et al., 2014; Galal \& Soliman, 2017).

Institutional ownership is ownership of company shares owned by institutions or institutions such as insurance companies, banks, investment companies, and other institutional ownership. Institutional ownership has an important meaning in monitoring management because the presence of institutional ownership will encourage increased oversight which is more optimal. Institutional ownership as one of the governance factors that influence company performance, institutional share ownership helps prevent managerial opportunistic behavior which in turn increases company performance (Gugong et al., 2014). Gugong et al. (2014), revealed a significant relationship between institutional share ownership and two financial performance measures (ROA and ROE). In addition, other research also revealed that institutional ownership had a significant positive effect on company performance/company profitability as measured through ROE (Husein Tahir, 2015; Pirzada et al., 2015). Based on this the research hypothesis is as follows:

Hla: Foreign ownership has a significant positive effect on profitability

HIb: Managerial ownership has a significant positive effect on profitability

H1c: Institutional ownership has a significant positive effect on profitability

\section{Firm Size}

The firm size can be described in the company's financial capability in a certain period, both based on assets in the form of current assets and fixed assets owned (Mule et al., 2015). The size of a large company, is considered as an indicator that illustrates a high level of risk for the company. The firm size can be expressed in total assets, sales, and market capitalization. The bigger the larger the firm size. Total assets, sales and market capitalization can be used to determine the firm size (Maria et al., 2019). 
According to Mule et al. (2015), there is a significant positive relationship between firm size and return on equity, where one unit change in firm size causes an increase in return on equity. Firm size is also an important positive predictor of profitability as measured by ROE (Mule et al., 2015). The same thing was also expressed in other studies which stated that the firm size measured from total assets significantly affected the profitability of the company as measured by ROE (Hirdinis, 2019). According to Olawale et al. (2016), firm size measured from total sales also has a positive effect on profitability (ROE). Based on this the research hypothesis is as follows:

H2: Firm size has a significant positive effect on profitability

\section{Firm Value}

The main objective of the company is to increase the firm value which is characterized by the level of prosperity of the company's shareholders. The firm value is also a benchmark for investors to assess the success of a company, where the higher the company's stock price means the higher the rate of return to investors and this means the higher the firm value is related to the objectives of the company itself, which is to maximize the prosperity of shareholders (Nurkhin et al., 2017). Involving management in the company's ownership structure is an effort to increase the firm value. Diverse ownership structure can encourage better company supervision, especially for the achievement of company goals, namely increasing the firm value.

Companies with foreign ownership are known to have better performance because the standards they have are almost the same as the standards of foreign companies which are usually better standards. According to Abukosim et al., (2014), foreign ownership has a significant positive effect on firm value (PBV). Other studies also reveal that foreign ownership has a positive effect on firm value as measured by PBV (Zakaria et al., 2014).

Management ownership is a shareholder of management who actively participates in company decision making. Managerial ownership shows the dual role of managers who also have a role as a shareholder of the company. Research conducted by Karima (2017), shows that managerial ownership has a significant influence on firm value. The same results are also shown by other studies where managerial ownership has a significant effect on firm value as measured by price-book value (PBV) (Putranto \& Kurniawan, 2018).

Institutional ownership usually has a large portion of ownership in a company, so institutional investors need to protect their investment in the company. High institutional ownership can lead to better monitoring or supervision of managers and can guarantee the prosperity of shareholders. Of course, this can affect firm value. Based on previous research, institutional ownership is known to have a positive and significant effect on firm value (PBV) (Abukosim et al., 2014; Wimelda \& Siregar, 2017; Faidah, 2018; Aghara et al.,2018; Pramana et al., 2019).

Firm size reflects the size or number of assets owned by the company. The greater the size of a company shows that the company is experiencing growth. Developing companies will increase firm value and be responded positively to investors. Generally, larger companies have greater sensitivity and relatively greater wealth transfers compared to smaller companies. With more sales, the faster the company reaches its goals. Thus, the firm size reflects the size or number of assets owned by the company and has an influence on the firm value (Horne \& Wachowicz, 2009). The firm size is proven to have a significant positive effect on firm value (Khoiro et al., 2017; Tui et al., 2017; Yanti \& Dwirandra, 2019). Based on this, the research hypothesis is as follows:

H3a: Foreign ownership has a significant positive effect on firm value

H3b: Managerial ownership has a significant positive effect on firm value

H3c: Institutional ownership has a significant positive effect on firm value

H4: Firm size has a significant positive effect on firm value

\section{Profitability}

Profitability shows the level of net profit obtained by a company. The greater the profits, the greater the company's ability to pay dividends. This will certainly attract the attention of investors and show good company performance. The size of profitability can be seen from various factors such as operating income, net income, the rate of return on investment/assets and the rate of return on owner's equity. Various policies are taken by management in an effort to increase the firm value through increasing the prosperity of owners and shareholders as reflected in the share price. Analysis of the firm value will provide the usefulness of information to investors in assessing the prospects of the company in the future in generating profits. The measured profitability of a company's ROE is known to have a significant positive effect on firm value as measured by PBV (Majid \& Benazir, 2015; Rahma et al., 2017; Tui et al., 2017; Dewi \& Dewi, 2017).

Sugosha, M. J., \& Artini, L. G. S. (2020). The role of profitability in mediating company ownership structure and size of firm value in the pharmaceutical industry on the Indonesia stock exchange. International Research Journal of Management, IT and Social Sciences, 7(1), 104-115. https://doi.org/10.21744/irjmis.v7n1.827 
Profitability is the company's ability to generate profits that are considered to be a signal for companies to attract investors to invest their capital. Companies with high levels of profitability will increase the effect of ownership structure on firm value (Nurkhin et al., 2017).

Profitability which illustrates the company's ability to make a profit is also certainly closely related to the number of sales or assets owned by the company. Related to this, the firm size can be stated in total assets, sales, and market capitalization. The greater the total assets, sales, and market capitalization, the greater the firm size (Maria et al., 2019). Based on this research hypothesis is as follows:

H5: Profitability has a significant positive effect on firm value

H6a: Profitability is able to mediate the relationship between foreign ownership and firm size

H6b: Profitability is able to mediate the relationship between managerial ownership and firm value

H6c: Profitability is able to mediate the relationship between institutional ownership and firm value

H7: Profitability is able to mediate the relationship between firm size and firm value.

\section{Materials and Methods}

This study uses the annual pharmaceutical industry to report data on the Indonesia Stock Exchange in the period 20132018. Sampling in this study using purposive sampling techniques and analyzed by path analysis method. Total samples taken were 7 pharmaceutical industry companies, namely Darya-Varia Laboratoria, Tbk. (DVLA), Kimia Farma, Tbk. (KAEF), Kalbe Farma, Tbk. (KLBF), Merck Tbk. (MERK), Pyridam Farma, Tbk. (PYFA), Sido Mamu Pharmaceutical Herbal Industry Tbk Appears. (SIDO) and Tempo Scan Pacific, Tbk. (TSPC).

The structural model in this study consists of foreign ownership variables (FOREIGN), managerial ownership (MNG), institutional ownership (INST) and firm size (SIZE) as independent variables. Firm value variable (PBV) as the dependent variable and profitability variable (ROE) as a mediating variable.

The ownership structure variables analyzed in this study were obtained from the percentage of foreign ownership, managerial ownership and institutional ownership found in each sample. The firm size variable is obtained from the result of the natural logarithm of the total assets of all samples at the end of the year. The profitability variable is obtained from the Return on Equity (ROE) value or the percentage of net profit after tax divided by shareholder equity. The firm value variable is measured from the Price to Book Value (PBV) of all samples in the period 2013 - 2018.

\section{Results and Discussions}

\section{Path Analysis Results}

Path analysis is used in this study to examine the direct and indirect effects of the ownership structure, firm size and profitability variables on firm value. The path analysis results are obtained by using regression using SPSS 24 .

\section{Equations in Path Analysis}

The structural model I includes the relationship between ownership structure variables and firm size on profitability (ROE), while structural model II includes the relationship between ownership structure variables, firm size and profitability (ROE) on firm value (PBV). The results of the path analysis of structural model I and structural model II show the magnitude of influence between variables in the model both direct and indirect effects. Based on these results we can also calculate the structural model error value I (e1) and the structural model error value II (e2). The path analysis results in this study are as follows:

Structural Model I:

$\mathrm{Y}_{1}=\beta_{1} \mathrm{X} 1+\beta_{2} \mathrm{X} 2+\beta_{3} \mathrm{X} 3+\beta_{4} \mathrm{X} 4+\mathrm{e}_{1}$

$\mathrm{ROE}=\beta_{1} \cdot$ FOREIGN $+\beta_{2} \cdot \mathrm{MNG}+\beta_{3} \cdot \mathrm{INST}+\beta_{4} \cdot \mathrm{SIZE}+\mathrm{e}_{1}$

$\mathrm{ROE}=0,665$ FOREIGN + 0,385 MNG + 0,177 INST + 0,772 SIZE + $\mathrm{e}_{1}$

$\mathrm{e}_{1}=\sqrt{\left(1-R^{2}\right)}=\sqrt{\left(1-(0.399)^{2}\right)}=0.917$ 
Structural Model II:

$\mathrm{Y}_{2}=\beta_{5} \mathrm{X} 1+\beta_{6} \mathrm{X} 2+\beta_{7} \mathrm{X} 3+\beta_{8} \mathrm{X} 4+\beta_{9} \mathrm{Z}+\mathrm{e}_{2}$

$\mathrm{PBV}=\beta_{5} \mathrm{FOREIGN}+\beta_{6} \mathrm{MNG}+\beta_{7} \mathrm{INST}+\beta_{8} \mathrm{SIZE}+\beta_{9} \mathrm{ROE}+\mathrm{e}_{2}$

$\mathrm{PBV}=0,097$ FOREIGN - 0,068 MNG + 0,094 INST + 0,291 SIZE + 0,424 ROE + $\mathrm{e}_{2}$

$\mathrm{e}_{2}=\sqrt{\left(1-R^{2}\right)}=\sqrt{\left(1-(0.425)^{2}\right)}=0.905$

\section{Model Validation}

Model validation in this study uses the total determination coefficient method that can be calculated using the total determination formula to obtain the following calculation results:

$$
\begin{aligned}
\mathrm{R}^{2} \mathrm{~m} & =1-\left(\mathrm{e}_{1}\right)^{2}\left(\mathrm{e}_{2}\right)^{2} \\
& =1-(0,917)^{2}(0,905)^{2}=1-(0,841)(0,819) \\
& =1-0,689=0,311
\end{aligned}
$$

The results of the model validation show that the variation of data influenced by the model by $31.1 \%$ means that the information contained in the data of $31.1 \%$ can be explained by the model, while the remaining $68.9 \%$ is explained by other variables outside the model.

\section{Sobel Test Results}

The Sobel test is used to determine whether mediating variables can influence the relationship of the independent variable with the dependent variable or not. The mediating variable tested in this study is profitability measured by the ROE variable. The Sobel test in this study was carried out with the Sobel formula (Preacher \& Hayes, 2004). The calculation results of the Sobel test in this study can be seen in table 1.

Table 1

Sobel test

\begin{tabular}{lllll}
\hline & Foreign & MNG & INST & Size \\
\hline $\mathrm{a}$ & 0.012 & 0.009 & 0.004 & 0.364 \\
$\mathrm{~b}$ & 1.405 & 1.405 & 1.405 & 1.405 \\
$\mathrm{SEa}$ & 0.003 & 0.005 & 0.005 & 0.094 \\
$\mathrm{SEb}$ & 0.540 & 0.540 & 0.540 & 0.540 \\
$\mathrm{Z}$ (sobel) & 2.181 & 1.480 & 0.765 & 2.159 \\
Information & Being able to mediate & No mediating & No mediating & Being able to mediate
\end{tabular}

Secondary Data, 2019

Table 1 shows that the Sobel value for FOREIGN is $2.181>1.96$ so the results of the analysis indicate profitability is able to mediate the effect of foreign ownership on firm value. Sobel SIZE value is 2.159>1.96 so that profitability is also able to mediate the effect of firm size on firm value, while the Sobel value for MNG $(1,480)$ and INST (0.765) is smaller than 1.96 so profitability has not been able to mediate managerial ownership and ownership institutional to firm size.

\section{Hla: Foreign ownership has a significant positive effect on profitability}

The path analysis results show that the significance value of FOREIGN on ROE is $0.001<0.05$. The beta coefficient of FOREIGN against ROE is 0.665 . This value means that foreign ownership has a significant positive effect on profitability, so hypothesis $1 \mathrm{a}(\mathrm{H} 1 \mathrm{a})$ is accepted.

Foreign ownership can increase profitability because foreign investors (PMA) are investors who are able to encourage companies, in this case, the pharmaceutical industry to improve the quality of companies especially in carrying out corporate governance. Foreign owners can also provide access to large resources and provide better monitoring and management expertise.

Sugosha, M. J., \& Artini, L. G. S. (2020). The role of profitability in mediating company ownership structure and size of firm value in the pharmaceutical industry on the Indonesia stock exchange. International Research Journal of Management, IT and Social Sciences, 7(1), 104-115. https://doi.org/10.21744/irjmis.v7n1.827 
This positive relationship between foreign ownership and profitability is supported by the results of Zakaria et al. (2014); Shrivastav \& Kalsie (2017); and Zraiq \& Fadzil (2018), which stated that foreign ownership is known to have a positive and significant relationship with company profitability.

\section{HIb: Managerial ownership has a significant positive effect on profitability}

The path analysis results show that the significance value of MNG on ROE is $0.434>0.05$. The beta coefficient of MNG against ROE is 0.385 . This value means that managerial ownership has no significant positive effect on profitability, so hypothesis $1 \mathrm{~b}(\mathrm{H} 1 \mathrm{~b})$ is rejected.

Managerial ownership does not have a significant positive effect on profitability in this study because the percentage of managerial ownership in the pharmaceutical industry on the Indonesia Stock Exchange in the period 2013 - 2018 has not shown a significant amount, so the determination of managerial policies is not strong enough to affect the company's performance in increasing profitability.

\section{H1c: Institutional ownership has a significant positive effect on profitability}

The results of the path analysis show that the significance value of INST on ROE is $0.070>0.05$. The beta coefficient of INST to ROE is 0.177 . This value means that institutional ownership does not have a significant positive effect on profitability, so hypothesis 1c (H1c) is rejected.

Institutional ownership does not affect the profitability of the company allegedly caused by the majority owner of the institution does not play an active role in controlling company performance. The results in this study are supported by research conducted by Dehkalani et al. (2015), and Pirzada et al. (2015), which states that institutional ownership has a negative influence on profitability.

\section{H2: Firm size has a significant positive effect on profitability}

The path analysis results show that the significance value of SIZE on ROE is $0,000<0.05$. The beta coefficient of SIZE against ROE is 0.722 . This value means that firm size has a significant positive effect on profitability, so hypothesis 2 (H2) is accepted.

A significant positive relationship between firm size and equity returns means that one unit change in firm size in the pharmaceutical industry causes an increase in equity returns in the pharmaceutical industry. This result is supported by research conducted by Mule et al. (2015); Olawale et al. (2016); and Hirdinis (2019), which stated that the firm size measured from total assets significantly affects the profitability of the company as measured by Return on Equity (ROE).

\section{H3a: Foreign ownership has a significant positive effect on firm value}

The path analysis results show that the FOREIGN significance value for PBV is $0.657>0.05$. The FOREIGN beta coefficient for PBV is 0.097 . The results show that foreign ownership has no significant positive effect on firm value, so hypothesis $3 \mathrm{a}(\mathrm{H} 3 \mathrm{a})$ is rejected. Foreign investors in the pharmaceutical industry on the Indonesia Stock Exchange in the period 2013 - 2018 do not necessarily have the same objectives as managerial to increase the firm value. Foreign investors tend to prioritize profits in investing their capital, so the percentage of foreign ownership may not necessarily increase the firm value in the pharmaceutical industry.

\section{H3b: Managerial ownership has a significant positive effect on firm value}

The path analysis results show that the significance value of MNG on PBV is $0.752>0.05$. The MNG beta coefficient for PBV is - (0.068). This value means that managerial ownership has a negative and not significant effect on firm value, so hypothesis $3 b(\mathrm{H} 3 b)$ is rejected. Managerial ownership has a negative and not significant effect on firm value because the portion of managerial ownership in the pharmaceutical industry has not been significant enough, so managerial ownership as an internal control tool in the pharmaceutical industry has not been able to effectively increase firm value. 
H3c: Institutional ownership has a significant positive effect on firm value

The results of the path analysis show that the significance value of INST on PBV is $0.676>0.05$. The beta coefficient of INST against PBV is 0.094 . This value means that institutional ownership has no significant positive effect on firm value, so hypothesis $3 \mathrm{c}(\mathrm{H} 3 \mathrm{c})$ is rejected.

institutional ownership does not have a significant positive effect on firm value allegedly because most institutional investors in the pharmaceutical industry on the Indonesia Stock Exchange in the period 2013 - 2018 did not actively oversee managerial performance in the company. Ownership of institutions that are too large can cause an ineffective monitoring agent function carried out by the institution so that supervision conducted by the institution cannot encourage the company to increase the firm value. The results of this study are supported by research conducted by Willim (2015) and Wimelda \& Siregar (2017), which state that institutional ownership has no significant effect on firm value.

\section{H4: Firm size has a significant positive effect on firm value}

The results of the path analysis show that the significance value of SIZE on PBV is $0.191>0.05$. The beta coefficient of SIZE against PBV is 0.291. This value means that firm size does not have a significant positive effect on firm value, so hypothesis $4(\mathrm{H} 4)$ is rejected. The firm size does not have a significant positive effect on firm value in this study because investors who will invest their capital in the pharmaceutical industry are not reviewed in terms of the total assets owned by the company.

\section{H5: Profitability has a significant positive effect on firm value}

The path analysis results show that the significance value of ROE on PBV is $0.013<0.05$. The beta coefficient of ROE against PBV is 0.424 . This value means that profitability has a significant positive effect on firm value, so hypothesis 5 (H5) is accepted.

Higher ROE indicates that the management is able to effectively and efficiently manage the capital invested by investors in the company so that the company's performance is getting more optimal and profits are increasing which will also lead to an increase in firm value. This result is supported by research conducted by Mussalam (2015) and Tui et al. (2017), which states that profitability has a significant positive effect on firm value. The higher the company's ability to generate profits, the greater the returns expected from investors, making the company's value better.

\section{H6a: Profitability is able to mediate the relationship between foreign ownership and firm size}

The path analysis results show that the value of foreign direct influence on firm value is 0.097 and the indirect effect of foreign ownership on firm value through profitability is 0.282 which means that the value of indirect influence is greater than the value of direct influence, this result shows that indirectly Foreign ownership through profitability has a significant influence on the firm value. Table 7 also shows that profitability is able to be a mediating variable of the effect of foreign ownership on firm value with the value of $\mathrm{z}$ (Sobel) being 2.181> 1.96 so that Hypothesis 6a (H6a) is accepted.

\section{H6b: Profitability is able to mediate the relationship between managerial ownership and firm value}

The path analysis results show that the value of the direct influence of managerial ownership on the firm value is $(0.068)$ and the indirect effect of managerial ownership on the firm value through profitability is 0.163 , which means that the value of the indirect effect is greater than the value of the direct influence, this result shows that indirectly managerial ownership through profitability has a significant effect on firm value, but table 7 shows that profitability is not able to mediate the effect of managerial ownership on firm value with a value of $\mathrm{z}$ (Sobel) is $1,480<1.96$ so Hypothesis $6 \mathrm{~b}(\mathrm{H} 6 \mathrm{~b})$ is rejected.

\section{H6c: Profitability is able to mediate the relationship between institutional ownership and firm value}

The path analysis results show that the value of direct influence of institutional ownership on firm value is 0.094 and the indirect effect of institutional ownership on firm value through profitability is 0.075 which means that the value of

Sugosha, M. J., \& Artini, L. G. S. (2020). The role of profitability in mediating company ownership structure and size of firm value in the pharmaceutical industry on the Indonesia stock exchange. International Research Journal of Management, IT and Social Sciences, 7(1), 104-115. https://doi.org/10.21744/irjmis.v7n1.827 
indirect influence is smaller than the value of direct influence, this result shows that indirectly foreign ownership through profitability has no significant effect on firm value. Table 7 also shows that profitability is not able to mediate the effect of institutional ownership on firm value with the value of $\mathrm{z}$ (Sobel) being $0.765<1.96$ so that Hypothesis $6 \mathrm{c}$ (H6c) is rejected.

\section{H7: Profitability is able to mediate the relationship between firm size and firm value}

The results of the path analysis show that the value of the direct effect of firm size on firm value is 0.291 and the indirect effect of firm size on firm value through profitability is 0.306 which means that the value of indirect influence is greater than the value of direct influence, these results indicate that indirectly firm size through profitability has a significant influence on firm value. Table 7 shows that profitability is able to be a mediating variable the effect of firm size on firm value with the value of $\mathrm{z}$ (Sobel) is 2.159> 1.96 so that Hypothesis 7 (H7) is accepted.

\section{Conclusion}

Based on the results of the analysis and discussion in this study it can be concluded as follows:

1) Foreign ownership has a significant positive effect on profitability in the pharmaceutical industry on the Indonesia Stock Exchange in the period 2013 - 2018, while managerial ownership and institutional ownership have no significant positive effect on profitability in the pharmaceutical industry on the Indonesia Stock Exchange in the period $2013-2018$.

2) The firm size has a significant positive effect on profitability in the pharmaceutical industry on the Indonesia Stock Exchange in the period 2013 - 2018

3) Foreign ownership, managerial ownership, and institutional ownership have no significant positive effect on the firm value in the pharmaceutical industry on the Indonesia Stock Exchange in the period 2013 - 2018.

4) The firm size has no significant positive effect on the firm value in the pharmaceutical industry on the Indonesia Stock Exchange in the period 2013 - 2018.

5) Profitability has a significant positive effect on firm value in the pharmaceutical industry on the Indonesia Stock Exchange in the period $2013-2018$.

6) Profitability is able to mediate the effect of foreign ownership on the firm value in the pharmaceutical industry on the Indonesia Stock Exchange in the period 2013 - 2018, but profitability is not able to mediate managerial ownership and institutional ownership of the firm value in the pharmaceutical industry on the Indonesia Stock Exchange in the period $2013-2018$.

7) Profitability is able to mediate the effect of firm size on firm value in the pharmaceutical industry on the Indonesia Stock Exchange in the period 2013 - 2018.

\section{Suggestion}

Suggestions for the pharmaceutical industry on the Indonesia Stock Exchange to better consider the ownership structure in the company, especially considering increasing foreign ownership in the pharmaceutical industry. High foreign ownership is expected to be able to increase company resources and encourage management to run better performance so as to improve operating results which leads to increased company profitability. The pharmaceutical industry is also expected to consider increasing the total assets of companies that are known to be able to increase company profits so that it can be an attraction for investors to invest in order to increase the firm value.

Future studies are suggested to examine how the role of profitability in mediating ownership structure and firm size on firm value so that the magnitude of the effect of profitability in mediating is known. Future studies are also expected to conduct research on the ownership structure, firm size, profitability and firm value variables in other company sectors and determine other variables that are more influential on firm value with profitability as a mediating variable. 
Conflict of interest statement

The authors declared that they have no competing interests.

Statement of authorship

The authors have a responsibility for the conception and design of the study. The authors have approved the final article.

\section{Acknowledgments}

The authors would like to thank the editor of IRJMIS for their valuable time, support and advice in completing the current study.

Sugosha, M. J., \& Artini, L. G. S. (2020). The role of profitability in mediating company ownership structure and size of firm value in the pharmaceutical industry on the Indonesia stock exchange. International Research Journal of Management, IT and Social Sciences, 7(1), 104-115. https://doi.org/10.21744/irjmis.v7n1.827 


\section{References}

Abukosim, A., \& Mukhtaruddin, M. (2014). Ownership structure and firm values: empirical study on Indonesia manufacturing listed companies. Journal of Art Science \& Commerce, (4), 1-14.

Aghara, V. N. O., Nwaizugbo, I. C., Oparah, P. C., \& Ifeanyichukwu, C. D. (2018). Sales promotion as a leverage strategy for improving sales and profitability in alcohol beverage industry. International Research Journal of Management, IT and Social Sciences, 5(4), 18-25. https://doi.org/10.21744/irjmis.v5n4.245

Alabdullah, T. T. Y. (2016). Are board size and ownership structure beneficial in emerging markets' firms? Evidence from Jordan. International Journal of Management \& Information Systems (IJMIS), $20(3), 87-94$. https://doi.org/10.19030/ijmis.v20i3.9752

Ali, H., \& Miftahurrohman, M. (2014). Pengaruh struktur kepemilikan saham, kebijakan dividen dan kebijakan hutang terhadap nilai perusahaan (studi pada perusahaan yang terdaftar di bei). Etikonomi, 13(2). https://doi.org/10.15408/etk.v13i2.1883

Brigham, E. F., \& Daves, P. R. (2014). Intermediate financial management. Cengage Learning.

Brigham, E. F., \& Houston, J. F. (2010). Dasar-dasar Manajemen Keuangan, Edisi 11 Buku 1. Jakarta: Salemba Empat.

Dehkalani, N. M., Asadi, A., \& Hamid, R. K. (2015). The Relationship between Institutional Ownership with the Current Financial Performance of the Firms Listed in Bombay Stock Exchange. International Journal of Management, Accounting and Economics, ISSN, 2383-2156.

Dewi, I. G. A. A. O., \& Dewi, I. G. A. A. P. (2017). Corporate social responsibility, green banking, and going concern on banking company in Indonesia stock exchange. International Journal of Social Sciences and Humanities, 1(3), 118-134. https://doi.org/10.29332/ijssh.v1n3.65

Fahdiansyah, R., Qudsi, J., \& Bachtiar, A. (2018). Struktur Kepemilikan Dan Nilai Perusahaan:(Studi Pada Perusahaan Manufaktur yang listing di Bursa Efek Indonesia). Jurnal Varian, 1(2), 41-49. https://doi.org/10.30812/varian.v1i2.70

Faidah, F. (2018). The effect of capital structure, corporate governance, liquidity and firm size on firm value with roe as intervening variables. Jurnal Ekonomi \& Bisnis, 19(3), 24-35.

Fauzi, H., \& Musallam, S. R. (2015). Corporate ownership and company performance: a study of Malaysian listed companies. Social Responsibility Journal, 11(3), 439-448. https://doi.org/10.1108/SRJ-05-2014-0064

Galal, H.M., \& Soliman, M.M. (2017). The Effect of Ownership Structure on Firm's Financial Performance: An Empirical Study on The Most Active Firms in The Egyptian Stock Exchange. European Journal of Business and Management. Vol.9, No.15.

Gugong, B. K., Arugu, L. O., \& Dandago, K. I. (2014). The impact of ownership structure on the financial performance of listed insurance firms in Nigeria. International Journal of Academic Research in Accounting, Finance and Management Sciences, 4(1), 409-416.

Herawanto, T. E., Kusman, M., Effendi, N.(2017). The Influence of Corporate Covernance and Ownership Structure on Profitability. Internasional Journal of Scientific and Research Publication, 7(7), 7-15.

Hirdinis, M. (2019). Capital structure and firm size on firm value moderated by profitability.

Horne, V., James, C., \& Wachowicz, J. M. (2009). Fundamentals of Financial Management, 13.

Hussain Tahir, S. (2015). Institutional ownership and corporate value: evidence from Karachi stock exchange (KSE) 30-index Pakistan. Praktični menadžment: stručni časopis za teoriju i praksu menadžmenta, 6(1), 41-49.

Karima, S. Y., \& Wuryaningsih, D. L. (2017). Pengaruh Struktur Kepemilikan, Keputusan Investasi, Dan Keputusan Pendanaan Terhadap Nilai Perusahaan (Kasus pada Perusahaan Manufaktur yang Terdaftar di Bursa Efek Indonesia Tahun 2013-2015) (Doctoral dissertation, Universitas Muhammadiyah Surakarta).

Kementerian Koordinator Bidang Perekonomian Republik Indonesia. 2018. Paket Kebijakan Ekonomi Minggu Ke-III November 2018 (Tahap XVI). Jakarta: Kementerian Koordinator Bidang Perekonomian Republik Indonesia.

Khoiro, E. E. U., Suhadak, S., \& Handayani, S. R. (2017). The influence of capital structure and firm size on profitability and dividend policy (An Empirical Study at Property and Real Estate Sector Listed in Indonesia Stock Exchange during the periods of 2009-2012). PROFIT (Jurnal Administrasi Bisnis), 10(2), 1-10. https://doi.org/10.21776/ub.profit.2016.010.02.1

Lawal, O. D., Agbi, E. S., \& Mustapha, L. O. (2018). Effect of Ownership Structure on Financial Performance of Listed Insurance Firms in Nigeria. Journal of Accounting, Finance and Auditing Studies, 4(3), 123-148.

Lukas, S., \& Basuki, B. (2015). The implementation of good corporate governance and its impact on the financial performance of banking industry listed in IDX. The International Journal of Accounting and Business Society, $23(1), 47-72$. 
Majid, M. S. A. (2016). An Indirect Impact of the Price to Book Value to the Stock Returns: An Empirical Evidence from the Property Companies in Indonesia. Jurnal Akuntansi dan Keuangan, 17(2), 91-96. https://doi.org/10.9744/jak.17.2.91-96

Maria, M., Wiagustini, L. P., \& Sedana, I. P. (2018). Pengaruh Ukuran Perusahaan, Leverage Dan Liquiditas Terhadap Profitabilitas Di Perusahaan Esperanca Timor-Oan (ETO) Dili Timor-Leste. E-Jurnal Ekonomi dan Bisnis Universitas Udayana, 23-40. https://doi.org/10.24843/EEB.2019.v08.101.p02

Mule, K. R., Mukras, M. S., \& Nzioka, O. M. (2015). Corporate size, profitability and market value: An econometric panel analysis of listed firms in Kenya.

Musallam, S. R. (2015). Relationships between ownership structures and corporate performance: Evidence from Malaysia. Mediterranean Journal of Social Sciences, 6(3 S1), 70. http://dx.doi.org/10.5901/mjss.2015.v6n3s1p70

Nurkhin, A., Wahyudin, A., \& Fajriah, A. S. A. (2017). Relevansi Struktur Kepemilikan Terhadap Profitabilitas dan Nilai Perusahaan Barang Konsumsi. Jurnal Akuntansi Multiparadigma, 8(1), 35-46. http://dx.doi.org/10.18202/jamal.2017.04.7038

Olawale, L. S., Ilo, B. M., \& Lawal, F. K. (2017). The effect of firm size on performance of firms in Nigeria. Aestimatio: The IEB International Journal of Finance, (15), 68-87.

Pirzada, K., Mustapha, M. Z. B., \& Wickramasinghe, D. (2015). Firm Performance, Institutional Ownership and Capital Structure: A Case of Malaysia. Procedia-Social and Behavioral Sciences, 211, 170-176. https://doi.org/10.1016/j.sbspro.2015.11.025

Pramana, Y., Suprasto, H. B., Putri, I. G. A. M. D., \& Budiasih, I. G. A. N. (2019). Fraud factors of financial statements on construction industry in Indonesia stock exchange. International Journal of Social Sciences and Humanities, 3(2), 187-196. https://doi.org/10.29332/ijssh.v3n2.313

Preacher, K. J., \& Hayes, A. F. (2004). SPSS and SAS procedures for estimating indirect effects in simple mediation models. Behavior research methods, instruments, \& computers, 36(4), 717-731. https://doi.org/10.3758/BF03206553

Putranto, P., \& Elan, K. (2018). Effect of Managerial Ownership and Profitability on Firm Value (Emprical Study on Food and Beverage Industrial Sector Company 2012 to 2015). European Journal Bussiness and Management, 10(25), 2018.

Rahma, D. A., Makhdalena, M., \& Trisnawati, F. Pengaruh CSR, Profitabilitas, Ukuran Perusahaan Dan Leverage Terhadap Nilai Perusahaan Pada Perusahaan Manufaktur Yang Terdaftar Di Bursa Efek Indonesia. Jurnal Online Mahasiswa Fakultas Keguruan dan Ilmu Pendidikan Universitas Riau, 5(1), 1-13.

Rahman, S. (2012). The role of intellectual capital in determining differences between stock market and financial performance. International Research Journal of Finance and Economics, 89(1), 46-77.

Shrivastav, S. M., \& Kalsie, A. (2017). The Relationship between Foreign Ownership and Firm Performance in India: An Empirical Analysis. Artha Vijnana, 59(2), 152-162.

Tui, S., Nurnajamuddin, M., Sufri, M., \& Nirwana, A. (2017). Determinants of Profitability and Firm Value: Evidence from Indonesian Banks. Social Sciences, 7(01). http://dx.doi.org/10.21013/jmss.v7.n1.p10

Willim, A. P. (2015). Price Book Value \& Tobin's Q: Which One is Better For Measure Corporate Governance?.

Wimelda, L., \& Siregar, S. V. (2017). The Effect of Financial Institution Ownership on Firm Value. Corporate Ownership and Control, 14(2), 114-122.

Yanti, N. M. Y. W. A., \& Dwirandra, A. (2019). The effect of profitability in income smoothing practice with good corporate governance and dividend of payout ratio as a moderation variable. International Research Journal of Management, IT and Social Sciences, 6(2), 12-21. https://doi.org/10.21744/irjmis.v6n2.601

Zakaria, Z., Purhanudin, N., \& Palanimally, Y. R. (2014). Ownership structure and firm performance: Evidence from Malaysian trading and services sector. European Journal of Business and Social Sciences, 3(2), 32-43.

Zraiq, M. A. A., \& Fadzil, F. H. B. (2018). The impact of ownership structure on firm performance: Evidence from Jordan. International Journal of Accounting, Finance and Risk Management, 3(1), 1-4.

Sugosha, M. J., \& Artini, L. G. S. (2020). The role of profitability in mediating company ownership structure and size of firm value in the pharmaceutical industry on the Indonesia stock exchange. International Research Journal of Management, IT and Social Sciences, 7(1), 104-115. https://doi.org/10.21744/irjmis.v7n1.827 